\title{
Inquiry-Based Learning in Teacher Training
}

\author{
Wolfgang Fichten
}

In recent years, inquiry-based learning has become an integral part of teacher training as a guiding principle of a contemporary university education. The background to this is the development of new educational and study concepts on the one hand, and the structural changes resulting from the implementation of the Bologna Process on the other. This article examines the experiences and research findings on inquiry-based learning in the teaching certification program and discusses perspectives on this.

\subsection{Teacher Training as a Context for Inquiry-Based Learning}

In recent years, inquiry-based learning has become broadly established in university teacher education and has virtually become a guiding principle. In the course of the discussion about reforming teacher education, inquiry-based learning gained special significance. The reasons for the "career" of this higher education didactic concept within the context of reflective, research-oriented or research-focused teacher education are complex and can only be outlined here.

Scholarly Orientation - Skills Orientation - Practice Orientation The Bologna process requires institutions of higher learning to align themselves with the goals of "employability" and skills development, i.e. the student's ability to pursue a professional activity based on scholarly work (cf. in addition BAK 1970, p. 9). From this perspective, how the university will contribute to the qualification of future teachers must be specified. According to

W. Fichten, Prof. Dr. ( ()

Carl von Ossietzky Universität Oldenburg - Leiter der „Forschungswerkstatt Schule und

LehrerInnenbildung “ im Didaktischen Zentrum, Oldenburg, Germany

e-mail: forschungswerkstatt@uni-oldenburg.de

H. A. Mieg (ed.), Inquiry-Based Learning - Undergraduate Research, 
the consensus, scholarship can provide a basis for professional action by providing and imparting scholarly theoretical and foundational knowledge. Students should be taught theoretical knowledge and methodological skills for the analysis of and reflection on practices. If scholarship is to have any significance for later professional activity, it must not remain unknown to students; instead, they must take part in the process of acquiring scholarly knowledge. Such "participation in scholarship" (BAK 1970, p. 9) has its educationaltheoretical basis: "if scholarship educates, then only scholarship that one 'works through' oneself as unconcluded; not scholarship that is merely imparted as concluded" (Huber 2009, p. 13, translated).

An Explorative Attitude as a Prerequisite for Dealing with Uncertainties Regarding the scholarly nature of the education and, in consequence, scholarship-based professional activity, the German Science Council (Wissenschaftsrat 2001, p. 41, translated) determined the following: "A university education should teach and promote the attitude of inquiry-based learning in order to enable future teachers to use their theoretical knowledge for analyzing and shaping the professional field, and in this way, should not teach in a manner that is distanced from scholarship, but instead, should teach with an investigative attitude." Research into professionalization has examined the complexity of teaching in greater detail: Teaching activities are accompanied by an irresolvable element of insecurity. Although recourse to routines that have been developed over time is possible on a limited basis, these routines fail in novel situational constellations, which therefore require a reflective type of action ("reflection on action," see also Huber, in this volume). In dealing with the complexity typical of a given occupation, a type of "researching within the context of practice" (forming hypotheses, creating, testing and evaluating alternative actions) or an experimental attitude is required, which can be acquired and developed through inquiry-based learning.

Developing an Investigative Habit The model of the professional derived from research findings was used to delineate an ideal image of an instructor who is capable of constantly critically examining their own goals, of generating alternative interpretations of practical conditions and of developing new perspectives. In order to succeed productively, the instructor must not only have an inventory of suitable methods available to them but above all must have a critical reflexive attitude towards the practice that fosters development through inquiry. In the discourse on inquiry-based learning, "a habit developed through the issues and methods of scholarly activity" (Terhart 2000, p. 69, translated) or an "investigative habit" is an essential target component. What is meant here is the internalization of a curious, skeptical view of the practice, which adopts the mode of scholarly inquiry, making certainties consistently available. Such an attitude makes it possible to question pedagogic activities as well as the understanding of school and teaching, in order to gain orientation for future action. It is aimed both at mastering practice by generating one's own solutions to problems and at fostering the professional development of the instructor. 


\subsection{Contours of Inquiry-Based Learning}

The slogan "professionalization through inquiry-based learning" has become a commonplace in academic discourse. Ludwig Huber (2009) criticizes the "inflationary" use of the term, which threatens to blur the contours of the concept. Koch-Priewe and Thiele (2009, p. 271) state that the concept has "innumerable facets" and allows for numerous variants. A common feature of the realization approaches documented in Roters, Schneider, KochPriewe, Thiele and Wildt (2009) is that inquiry-based learning is primarily directed "at different forms of reflectivity and participation in scholarly, methodological discourse" (ibid., p. 279, translated). Wischer, Katenbrink and Nakamura (2014, p. 12 et seq.) attribute the diversity to the "context-specific basic conditions and formal structures that allow inquiry-based learning [...] to be developed in the respective degree programs in the first place" as well as the absence of a definition on which a consensus can be reached. There is no consensus on the question as to "what inquiry-based learning is even supposed to achieve and what conditions must exist so that the respective goals can be reached" (ibid., p. 15 , translated).

The following definition clarifies the concept: "Within the context of teacher training, inquiry-based learning is understood to be the acquisition of experience, knowledge and competencies based on a self-reflective and theory-based confrontation with school as an area of activity" (Ministerium für Schule, Jugend und Kinder des Landes NordrheinWestfalen, cited in Wilde and Stiller 2011, p. 171, translated).

While Huber's definition (see, for example, Mieg, in this volume) places the research process in the foreground and emphasizes the aspect of independence, the goal and result of inquiry-based learning are addressed in the quoted definition: The component of reflection can be situated in the discourse on professionalization, while the reference to theory can be justified by the academic nature of a university education. Both components are mutually dependent, since it is indispensable for reflection intended to question one's own subjective theories to reference scholarly theories.

Accordingly, inquiry-based learning exhibits three central characteristics: independence, relation to theory, and reflection. It is not easy to implement these characteristics, as the descriptions of various course formats show (Roters et al. 2009; Huber et al. 2009; Katenbrink et al. 2014). Ideally, seminar concepts should be geared towards meeting all three criteria. This shows that the realization of inquiry-based learning is a didactically demanding task that may not be mastered right away, which - in a manner analogous to that of school instruction - suggests an experimental approach to one's own higher education instruction. 


\subsubsection{Approaches and Formats of Inquiry-Based Learning}

As noted, inquiry-based learning in teacher training encompasses a wide spectrum that ranges from its inclusion in practical studies, compulsory elective modules in the educational sciences and its establishment in internships requiring intense supervision. The variety has forced attempts at classification, which can be based, inter alia, on the aspects of participation (cf. Fichten 2010, p. 149) and dimensioning. The spectrum extends from limited observation tasks in a general school internship/job orientation internship to comprehensive projects within the context of research modules based on educational science and of the practical semester. In the course of implementing inquiry-based learning in teacher training, consequential determinations were arrived at. Very little attention has been paid to the approach developed by Huber (2009, p. 18), who mentions various implementation options that allow students a high degree of independent activity in complex task formats, taking into account discipline-related conditions (researching, excursions, simulations, etc.).

The "internship solution" is currently the most common form of inquiry-based learning - in many places, it's the only form. One of its positive aspects is that it allows the individual's own practice can be taken into consideration. Academic studies' increased orientation towards practice and the subsequent expansion of the practical part of those studies do not guarantee unto themselves that prospective instructors will later work professionally in that occupation, however, since there is a risk that the practices observed will be adopted without reflection. Inquiry-based learning is intended to counteract this and contribute to a perception and analysis of the practice at a distance, from a position of observation associated with research.

Linking student research with internships has far-reaching consequences for students as well as for supervising instructors, because it makes inquiry-based learning a compulsory study component for all. This corresponds to the position of the Federal University Assistants' Conference (BAK 1970): "participation in scholarship" for all, and right from the start. Inquiry-based learning is an element of academic studies that requires intensive supervision; instructors' limited capacities must be distributed among larger groups. In addition, academic achievement must be certified and assessed. The inquiry-based learning that was established in the old degree programs took the form of an elective course that was used by particularly interested and motivated students. If inquiry-based learning is obligatory for all, it can no longer be assumed that one is only dealing with motivated students, meaning the issue of motivation must be raised in an entirely different way (cf. Huber 2009).

\subsubsection{Realization Approaches}

Inquiry-based learning that is not linked to internships has been increasingly used in teacher training since the end of the 1990s. As such, the focus is placed less on individual professionalization, and more on the benefits for school and teaching development. 
Oldenburg team research is an example of this (Fichten and Meyer 2009). Instructors participate in seminar sessions and actively participate in research based on two-hour blocks of time. Teams comprised of instructors and students research issues that arise from within a school context. Research projects are oriented towards action research; their aim is to generate solutions or a framework of action for school and teaching-related problems. The team research program, which has existed since 1996, was carried out as a one- to two-semester seminar within the scope of a pedagogic portion of academic studies. Comparable courses exist at other locations (e.g. Bielefeld, Hamburg, Osnabrück).

Evaluation results concerning team research show that students take away a changed view of the problem from their involvement in the research, i.e. personal assumptions are relativized or changed (cf. Fichten and Moschner 2009, p. 251 et seq.). The intensive engagement with school-related issues (the relevance of which to one's own qualification becomes clear) contributes to students frequently pursuing the contents more deeply and more extensively (for example in state examination (Staatsexamen) theses or masters' theses). Students acquire interdisciplinary competencies (e.g. a capacity for teamwork or collaboration) as well as research competence. In their own estimation, they are better able to evaluate published research reports and have a more differentiated and critical view of scholarship. In view of the limited theoretical framing of the projects, the increased appreciation of scholarly theory by some students is somewhat surprising.

The concept at RWTH Aachen (Boelhauve 2009) presents an example of an "internship solution" which provides one gradation of inquiry-based learning. The first element of inquiry-based learning is linked to the introductory school internship during the basic studies (Grundstudium). In the preparatory seminar, central tasks of the teaching profession are developed; these provide a "structuring instrument" for the focal points of the observation task to be performed during the internship. The educational science and the teaching methodologies of two subjects are involved in the "field studies" module during the primary studies (Hauptstudium). During the internship, students carry out previously agreed-upon "investigative tasks" that have been framed in terms of educational and didactic theory. They may select the subject on which the content of the project will focus from among the disciplines involved in the module.

The introduction of the practical semester - which has been completed in some federal states of Germany, and is pending in others - creates further possibilities for implementing inquiry-based learning. The practical semester in Lower Saxony, which was introduced for the degree programs for elementary, secondary and junior high school education, includes what is known as a "practical block," during which the students themselves teach up to 40 hours. In addition, this block also includes the Projektband or project phase (in other federal states: study project, research task), in which an empirical study relating to school or instruction must be conducted; a number of variations for this study are specified (cf. Klewin and Schüssler 2012: Varianten der Studienprojekte in NRW). There is adequate time for student research projects due to the length of the practical semester. However, in addition to the observed lessons, the interns involved in the program must also prepare and teach their own lessons and so they cannot focus exclusively on their research project. 
An example from biology didactics at the University of Bielefeld shows how inquirybased learning can be shaped during the practical semester (Wilde and Stiller 2011). In the preparatory seminar, theories that are relevant to biology didactics and their possible applications are presented in class, along with lesson-planning methods. After the theoretical portion of each seminar session, an attempt should be made to integrate the respective theory into concrete lesson plans (presentation of different lesson designs and assessment of the same against the backdrop of theory). The methodological foundations for student study projects will be imparted in the supervision seminar and linked with issues that are based on theories relating to biology didactics. Students will then create a lesson plan and a questionnaire for class evaluation, taking into account the selected theory. The lesson is held and evaluated with regard to the respective issue, and the results are presented in a project report or as a poster.

Experiences with inquiry-based learning in teacher training are as varied as the formats. There are nevertheless some convergences:

- Inquiry-based learning succeeds when the seminar is designed with a balance of guidance and independence. In the case of Oldenburg team research, the percentage of direct instruction alternates with extensive phases of self-regulated teamwork and additionally required individual work.

- Inquiry-based learning focuses on students' learning gains. As newcomers to research, students must be taught research competence so that they can carry out an empirical investigation to their own satisfaction and mark it down as a success. If this does not happen, it will hinder the development of an investigative habit.

- Depending on the format, the student projects are determined by the needs and problems expressed by schools, or by contents imparted in the preparatory seminar, the practical relevance of which is to be examined.

- Teaching both research methods and disciplinary content in a single seminar results in an overload. A combination of courses belonging to a module with primarily researchrelated and content-oriented seminars appears to be a suitable system.

\subsubsection{Perspectives on Inquiry-Based Learning in Teacher Training}

Given its widespread establishment in university teacher education, it is not particularly daring to predict that, in the future, inquiry-based learning will continue to play a role as an element of academic studies and will be significant in the training of prospective teachers. The extent to which it will sustain its position, however, depends on the processing of questions that have arisen over the years regarding site-specific implementation.

In its implementation in teacher education, inquiry-based learning has become associated with a number of goals, requirements and effects that must be implemented due to the inclusion of various discourses (professionalization, competence and practice orientation, etc.), and thus the original approach and the intention associated therewith are scarcely 
recognizable. For example, the educational-theoretical reasoning set forth in the BAK paper (1970) has receded into the background these days, where the focus is not so much on personal development as it is on professional qualification. In view of what is, in principle, welcome diversity in the available interpretations and approaches to implementation, which can also lead to arbitrariness, it is necessary to understand fundamental features of inquiry-based learning, as well as to clarify and contour the concept.

A further problem area stands out with regard to positioning the curriculum of inquirybased learning. Katenbrink and Wischer (2014, p. 122) have noted a tendency for inquirybased learning "to be added, as it were, to other targeted competencies and concepts of teacher education." Imparting research competence, for example, is "simply added to the already diverse goals, standards and competence profiles for teacher training" (ibid., p. 123). The lack of or insufficient integration of student research into the overall curriculum means, inter alia, that when inquiry-based learning is situated later in the course of study, students have very little knowledge on which to build. The positioning of the curriculum must not be limited to the module level, but must instead be based on the entire course of studies and lead to the construction of a spiral curriculum that allows connections to be made within.

Attention is paid to the various institutional relationships and constellations of agents associated with the implementation of the concept. Since student projects are established at the school, the school's expectations, interests and requirements also come into play. There is a need for coordination and clarification (e.g. with reference to the participation of study groups in research studies, contact persons at the school, etc.). As such, obligations and responsibilities must also be specified and defined. One problem, among several, is that the timing of events at the university and at school differ, and therefore there is usually only a limited timeframe for student projects, with the exception of the practical semester.

What should be decisive for the prospects of inquiry-based learning in teacher education is whether - and the degree to which - the intended goals are reached and the postulated effects occur. Available evaluation results indicate that some target components have been reached (see above). The validity of the findings is limited, however, since it is not possible to determine which effects are attributable to the respective settings and contexts, and which are genuinely attributable to inquiry-based learning. Among other things, the question arises as to the level of reflection students achieve through the practical semester and inquiry-based learning. The "bulky" construct of reflective competence has already been operationalized for studies in this regard (cf. Leonhard et al. 2010).

In the case of inquiry-based learning, it is repeatedly emphasized that the process is more important than the results, and the development of research-oriented behavior is more decisive than the acquisition of knowledge. If one admits that inquiry-based learning primarily depends on the formation and internalization of certain dispositions and attitudes towards practice, and if one assumes that this is actually achieved, the question remains whether students will take this attitude from the university learning situation and transfer it to other situational contexts, and how stable that attitude will be (transfer and 
stability hypothesis; cf. Fichten 2010, p. 159). This means that, ultimately, it will only be possible to assess the effectiveness of inquiry-based learning more precisely by basing that assessment on comprehensive longitudinal studies, which currently have yet to be performed. If it should turn out that the envisaged research-oriented behavior is a short-lived, fleeting phenomenon, this would likely have repercussions for the extent to which the concept is used in teacher education.

A "scenario" of this kind is not too farfetched. The three phases of teacher education (university education phase, internship, further teacher education) should be considered as a single entity (Terhart 2000). The second phase is still centered on social integration into the profession and on "teaching classes." An explorative-developing, critical reflective attitude, which students have acquired via the first phase of inquiry-based learning, seems to be hardly in demand in internships and will therefore possibly be abandoned. Such an attitude is more likely to be permanent and to be included in the student's professional activity when all phases of teacher education include elements of inquiry-based learning. While the second phase has a deficit in this regard, there are isolated approaches and projects in further teacher training (e.g. Andreitz et al. 2014).

Klewin and Kneuper (2009, p. 84, translated) state: "Overall, it seems to be [...] necessary to first differentiate the precise description of students' learning processes in inquirybased learning processes in greater detail. Only then can the competencies (that can be) acquired within this process be grasped theoretically and then studied empirically." Some publications exist for this first step of the indicated pragmatic-inductive path, and it would be decisive for the prospects of inquiry-based learning in teacher education if we were to take the second step now.

\section{References}

Andreitz, I./Müller, F./Dirninger, E./Mayr, J. (2014). Bedingungen und Wirkungen forschenden Lernens in der Lehrer_innenfortbildung. Ergebnisse aus der Begleitforschung der Lehrgänge Pädagogik und Fachdidaktik für Lehrer_innen(PFL). In E. Feyerer/K. Hirschenhauser/K. SoukupAltrichter (Hrsg.), Last oder Lust? Forschung und Lehrer_innenbildung (S. 189-204). Münster: Waxmann.

Bundesassistentenkonferenz (BAK) (1970). Forschendes Lernen - Wissenschaftliches Prüfen. Schriften der BAK 5: Bonn.

Boelhauve, U. (2009). Forschendes Lernen im Rahmen von Praxisstudien im erziehungswissenschaftlichen Studium der Lehramtsausbildung an der RWTH Aachen. In B. Roters/R. Schneider, B/Koch-Priewe, J./Thiele/J. Wildt (Hrsg.), Forschendes Lernen im Lehramtsstudium (S. 37-62). Bad Heilbrunn: Klinkhardt.

Fichten, W. (2010). Forschendes Lernen in der Lehrerbildung. In U. Eberhardt (Hrsg.), Neue Impulse in der Hochschuldidaktik (S. 127-182). Wiesbaden: VS-Verlag.

Fichten, W./Meyer, H. (2009). Forschendes Lernen in der Lehrerbildung - das Oldenburger Modell. In N. Hollenbach/K.-J. Tillmann (Hrsg.), Die Schule forschend verändern. Praxisforschung aus nationaler und internationaler Perspektive (S. 119-145). Bad Heilbrunn: Klinkhardt.

Fichten, W./Moschner, B. (2009). Forschendes Lernen in der Oldenburger Lehrerbildung. In B. Roters/R. Schneider/B. Koch-Priewe/J. Thiele/J. Wildt (Hrsg.), Forschendes Lernen im Lehramtsstudium (S. 242-270). Bad Heilbrunn: Klinkhardt. 
Huber, L. (2009). Warum Forschendes Lernen nötig und möglich ist. In L. Huber/J. Hellmer/ F. Schneider (Hrsg.), Forschendes Lernen im Studium. Aktuelle Konzepte und Erfahrungen (S. 9-35). Bielefeld: Universitäts VerlagWebler.

Huber, L./Hellmer, J./Schneider, F. (Hrsg.). (2009). Forschendes Lernen im Studium. Aktuelle Konzepte und Erfahrungen. Bielefeld: UniversitätsVerlagWebler.

Katenbrink, N./Wischer, B. (2014). Konzepte forschenden Lernens in der Osnabrücker Lehrerbildung. Versuch einer Einordnung und Reflexion. In N. Katenbrink/B. Wischer/Y. Naka mura (Hrsg.), Forschendes Lernen in der Osnabrücker Lehrerausbildung (S. 109-131). Münster: MV Wissenschaft.

Katenbrink, N./Wischer, B./Nakamura, Y. (Hrsg.). (2014). Forschendes Lernen in der Osnabrücker Lehrerausbildung. Münster: MV Wissenschaft.

Klewin, G./Kneuper, D. (2009). Forschend lernen in der Bielefelder Fallstudienwerkstatt Schulentwicklung. In B. Roters/R. Schneider/B. Koch-Priewe/J. Thiele/J. Wildt (Hrsg.), Forschendes Lernen im Lehramtsstudium (S. 63-85). Bad Heilbrunn: Klinkhardt.

Klewin, G./Schüssler, R. (2012). Forschendes Lernen im Bielefelder Praxissemester. In C. Freitag/I. von Bargen (Hrsg.), Praxisforschung in der Lehrerbildung (S. 75-84). Berlin, Münster: LiT.

Koch-Priewe, B./Thiele, J. (2009). Versuch einer Systematisierung der hochschuldidaktischen Konzepte zum Forschenden Lernen. In B. Roters/R. Schneider/B. Koch-Priewe/J. Thiele/J. Wildt (Hrsg.), Forschendes Lernen im Lehramtsstudium (S. 271-292). Bad Heilbrunn: Klinkhardt.

Leonhard, T./Nagel, N./Rihm, T./Strittmatter-Haubold, V./Wengert-Richter, P. (2010). Zur Entwicklung von Reflexionskompetenz bei Lehramtsstudierenden. In A. Gehrmann/ U. Hericks/M. Lüders (Hrsg.), Bildungsstandards und Kompetenzmodelle (S. 111-127). Bad Heilbrunn: Klinkhardt.

Roters, B./Schneider, R./Koch-Priewe, B./Thiele, J./Wildt, J. (Hrsg.). (2009). Forschendes Lernen im Lehramtsstudium. Bad Heilbrunn: Klinkhardt.

Terhart, E. (2000). Perspektiven der Lehrerbildung in Deutschland. Abschlussbericht der von der Kultusministerkonferenz eingesetzten Kommission. Weinheim, Basel: Beltz.

Wilde, M./Stiller, C. (2011). Ansätze Forschenden Lernens in der Biologiedidaktik an der Uni Bielefeld. TRiOS, 6(2), 171-183.

Wischer, B./Katenbrink, N./Nakumura, Y. (2014). Forschendes Lernen in der (Osnabrücker) Lehrerbildung - eine einführende Problemskizze. In dies. (Hrsg.), Forschendes Lernen in der Osnabrücker Lehrerausbildung (S. 5-26). Münster: MV Wissenschaft.

Wissenschaftsrat (2001). Empfehlungen zur künftigen Struktur der Lehrerbildung. Drs. 5065/01. Berlin.

Open Access This chapter is licensed under the terms of the Creative Commons AttributionNonCommercial-NoDerivatives 4.0 International License (http://creativecommons.org/licenses/bync-nd/4.0/), which permits any noncommercial use, sharing, distribution and reproduction in any medium or format, as long as you give appropriate credit to the original author(s) and the source, provide a link to the Creative Commons licence and indicate if you modified the licensed material. You do not have permission under this license to share adapted material derived from this chapter or parts of it.

The images or other third party material in this chapter are included in the chapter's Creative Commons licence, unless indicated otherwise in a credit line to the material. If material is not included in the chapter's Creative Commons licence and your intended use is not permitted by statutory regulation or exceeds the permitted use, you will need to obtain permission directly from the copyright holder.

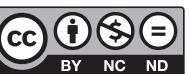

